https://doi.org/10.18778/7525-969-8.31

\author{
Szymon Sochacki
}

\title{
Aspiracje Bośni i Hercegowiny do członkostwa w NATO. Reforma sektora obronności
}

Podział Bośni i Hercegowiny $(\mathrm{BiH})$ na dwa podmioty, usankcjonowany przez układ pokojowy z Dayton, dotyczył również sił zbrojnych. Republika Serbska (RS) oraz Federacja Bośni i Hercegowiny (FBiH) dysponowały własnymi armiami, przy czym Wojsko Federacji (Vojska Federacije Bosne i Hercegovine, $\mathrm{VFBiH}^{1}$ ) składało się z dwóch komponentów - bośniackiego i chorwackiego. W 1996 r. liczebność żołnierzy i uzbrojonych rezerwistów w całej Bośni wynosiła 430 tys. $^{2}$ W latach $1995-2000 \mathrm{BiH}$ była jednym z najbardziej zmilitaryzowanych krajów regionu, do czego należy dodać najwyższy poziom wydatków na obronność. Istnienie dwóch armii w podmiotach powodowało, iż wydatki na obronność sięgały 10\% PKB każdego z podmiotów ${ }^{3}$. Dopiero z czasem i stopniowo udało się zmniejszyć tę ogromna liczbę żołnierzy.

Konstytucja Bośni ${ }^{4}$ nie określa jednoznacznie kwestii kompetencji organów państwowych z zakresu obronności. Według artykułu V.5.a wszystkie siły zbrojne w BiH będą funkcjonować w zgodzie z suwerennością i integralnością terytorialną tego kraju. Po drugie, żaden podmiot nie może grozić siłą ani używać przemocy wobec drugiego podmiotu. Po trzecie, podmiotom nie wolno przemieszczać swoich sił zbrojnych na terytorium drugiego podmiotu bez zgody jego rządu i Prezydium BiH. I po czwarte, każdy członek Prezydium BiH pełni z mocy urzędu funkcję cywilnego dowódcy sił zbrojnych. Przez wiele lat trwał

${ }^{1}$ Jest to bezpośredni przekład terminu „vojska”. Znane są bowiem w języku serbskim określenia: „armija” oraz „oružane snage” (,siły zbrojne”).

${ }^{2}$ D. Wybranowski, Bośnia i Hercegowina wobec Unii Europejskiej-trudna droga ku stowarzyszeniu. Problemy i wyzwania polityki UE na Batkanach Zachodnich na poczatku XXI wieku, „Wrocławskie Studia Politologiczne” 2009, nr 10, s. 229.

${ }^{3}$ H. Vetschera, Verteidingungsreform in Bosnien und Hercegowina, [w:] Bosnien und Hercegowina. Europa Balkanpolitik auf dem Prüfstand, Hrsg. E. Reiter, P. Jureković, Baden-Baden 2005, s. 105.

${ }^{4}$ Ustav Bosne i Hercegovine, oficjalna witryna internetowa Trybunału Konstytucyjnego BiH, http://www.ccbh.ba/public/down/USTAV_BOSNE_I_HERCEGOVINE_bos.pdf (dostęp 10 V 2011). 
spór, czy członkowie Prezydium maja pełnić funkcję cywilnego dowódcy tylko

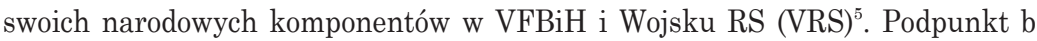
wyżej wymienionego artykułu mówi także, iż członkowie Prezydium powołuja Stały Komitet Wojskowy, który ma koordynować działania sił zbrojnych w BiH. Członkowie Prezydium z mocy urzędu wchodzą w skład Komitetu. Dokładna interpretacja wyżej cytowanego artykułu pokazuje jednak, że Prezydium $\mathrm{BiH}$ jako całość sprawuje cywilną kontrolę i dowództwo nad wszystkimi siłami zbrojnymi w BiH. Mogą to być armie podmiotów, jak również samej Bośni. Prezydium jest organem kolektywnym, również decyzje dotyczące sił zbrojnych muszą więc zapadać jednomyślnie i kolektywnie. Zwolennicy utworzenia jednej armii $\mathrm{BiH}$ oprócz wyżej wymienionego artykułu powoływali się także na art. III.5. konstytucji z Dayton ${ }^{6}$. Powiada on, że BiH jest kompetentna w sprawach, które dotycza zachowania suwerenności, integralności terytorialnej, niezawisłości politycznej i podmiotowości międzynarodowej $\mathrm{BiH}$. Dodaje również, iż w tej materii moga być tworzone dodatkowe instytucje. Niejednoznaczne, ogólnikowe i zarazem elastyczne przepisy ustawy zasadniczej w tym zakresie pozwoliły z czasem na utworzenie jednej armii BiH bez jakiejkolwiek nowelizacji konstytucji Bośni.

Wojsko FBiH powstało dzięki integracji Chorwackiej Rady Obrony (HVO) i Armii Republiki BiH (ARBiH) zgodnie z ustawa o obronie Federacji ${ }^{7}$. Znajdowało się ono pod cywilną kontrolą Ministerstwa Obrony, prezydenta i wiceprezydenta Federacji. Jego komponenty (chorwacki i bośniacki) podlegały kontroli bośniackiego i chorwackiego członka Prezydium BiH. Typowe dla jego struktury (ministerstwo obrony i Wspólne Dowództwo VFBiH) było istnienie dwuosobowych stanowisk wykonawczych (Bośniak i Chorwat). Decyzje w tych instytucjach były wiążace tylko przy zgodzie obydwóch. Stosunek sił w VFBiH wynosił 2,5: 1 na korzyść Bośniaków.

Wojsko RS $\left(V_{R S}^{8}\right)$ po podpisaniu układu w Dayton przeszło reorganizację, zachowując nazwę z okresu wojny. Głównodowodzącym VRS był prezydent RS i podlegało ono także kontroli serbskiego członka Prezydium BiH. W 2003 r. liczyło 6,6 tys. żołnierzy. Bośniaccy Serbowie traktowali posiadanie własnych sił zbrojnych jako symbol suwerenności i niezależności tego podmiotu. Z tego powodu wyrażali ostry sprzeciw wobec żądań zjednoczenia armii Federacji oraz RS i powołania wspólnych Sił Zbrojnych BiH (SZ BiH).

${ }^{5}$ O. Ibrahimagić, Državno uređenje Bosne $i$ Hercegovine. Ustavne teme $i$ političke dileme, Sarajevo 2005, s. 307.

${ }^{6}$ Tamże, s. 302; Put u Partnerstvo za mir: izvještaj Komisije za reformu u oblasti obrane, 25 IX 2003, oficjalna witryna internetowa Ministerstwa Obrony BiH, s. 2-3, http:// www.mod.gov.ba/files/file/dokumenti/ Partnerstvo-za-mir-bs.pdf (dostęp 10 X 2011).

${ }^{7}$ I. Alija, Odbrambena politika u tranzicijskom periodu Bosne $i$ Hercegovine, Sarajevo 2006, s. 145 .

8 Zob. przypis 1. 
Reforma sektora obronności w BiH została zainicjowana przez wspólnotę międzynarodowa, która już pod koniec lat 90 . XX w. rozpoczęła dialog w tej sprawie z władzami Bośni. Po spotkaniu Rady ds. Wdrażania Pokoju (PIC) w Madrycie w grudniu 1998 r. powstało Common Security Policy Working Group (CSPWG) pod egidą Biura Wysokiego Przedstawiciela (OHR), Sił Stabilizacyjnych (SFOR) i misji OBWE ${ }^{9}$ W związku z aktywną rolą Wysokiego Przedstawiciela, który na ogół inicjował reformy, utworzył on na początku 2002 r. Institution Building Task Force (IBTF), gdzie zasiedli przedstawiciele OHR, SFOR, OBWE i UE ${ }^{10}$. W ramach tej grupy znalazła się również CSPWG pod zmienioną nazwą Defense and Security Steering Group. Trwały tam prace nad projektami redukcji armii podmiotów oraz utworzenia wspólnych sił zbrojnych.

W czerwcu 2001 r. sekretarz generalny NATO określił kryteria przyjęcia Bośni do programu Partnerstwo dla Pokoju ${ }^{11}$. Wśród nich znalazł się wymóg ustanowienia efektywnego cywilnego dowodzenia oraz kontroli nad siłami zbrojnymi. Kompetencjami w łańcuchu dowodzenia miały dysponować tylko instytucje $\mathrm{BiH}$. Pakt wymagał także transparentności planów obronnych i budżetu, ustanowienia parlamentarnej kontroli nad siłami zbrojnymi, rozwoju wspólnej doktryny obronnej, wspólnych standardów szkolenia i wyposażenia sił zbrojnych oraz pełnej współpracy z Międzynarodowym Trybunałem Karnym dla byłej Jugosławii (ICTY).

Wspólnota międzynarodowa domagała się od podmiotów w pierwszej kolejności redukcji armii przynajmniej z dwóch powodów. Po pierwsze, armie obciążały zbyt poważnie budżety podmiotów. Po drugie, zmniejszenie stanów osobowych miało osłabić opór przed głównym celem, powołaniem wspólnych sił zbrojnych. Na spotkaniu PIC w Brukseli w dniach 23-24 maja 2000 r. ustalono, że wydatki na armie podmiotów oraz stany osobowe powinny zmaleć do końca 2000 r. o $15 \%{ }^{12}$. Na lata $2002-2005$ przyjęto plan redukcji armii do poziomu 13,2 tys. żołnierzy VFBiH oraz 6,6 tys. VRS. Warto zwrócić również uwagę, że w tym czasie NATO przygotowywało przekazanie misji wojskowej w Bośni Unii Europejskiej (misja EUFOR), co też nastapiło w dniu 2 grudnia $2004 \mathrm{r}$. Pakt po tej dacie nie wycofał się całkowicie z BiH. Nadal istnieje tam natowski ośrodek dowodzenia. Sojusz skupia się przede wszystkim na udziale w reformie bośniackiego systemu obronnego i przygotowaniu tego kraju do członkostwa w programie Partnerstwo dla Pokoju ${ }^{13}$. Jednostki natowskie, które pozostały,

${ }^{9}$ H. Vetschera, dz. cyt., s. 110.

10 Tamże, s. 111.

11 Tamize, s. 112.

${ }_{12}$ Deklaracija Vijeća za implementaciju mira, Brussels PIC Main Meeting, $24 \mathrm{~V} 2000$, oficjalna witryna internetowa OHR, http://www.ohr.int/pic/default.asp?content_id=6802 (dostęp 10 IX 2008).

${ }^{13}$ R. Serry, Ch. Bennett, Utrzymać kurs, oficjalna witryna internetowa NATO, http://www.nato.int/docu/review/2004/issue4/polish/art3.html (dostęp 30 V 2005). 
mają również za zadanie przeciwdziałać terroryzmowi i przeprowadzać poszukiwania i aresztowania osób podejrzanych lub już oskarżonych o popełnienie zbrodni wojennych ${ }^{14}$.

W Stałym Komitecie Wojskowym OHR widziało instytucję, którą należy przekształcić w centralne Ministerstwo Obrony. Komitet był jedynym organem wymienionym w konstytucji BiH, który miał zajmować się sprawami obronności. Problem polegał na tym, iż było to ciało kolegialne, natomiast ministerstwo powinno być raczej zorganizowane monokratycznie. Poza tym taki pomysł ignorował rozdział pomiędzy Prezydium i rządem BiH. W połowie 2002 r. wspólnota międzynarodowa zaproponowała członkom Prezydium BiH plan rozwoju Komitetu. W jego skład miało wejść dziewięć osób: trzech członków Prezydium, prezydent $\mathrm{RS}$, prezydent $\mathrm{i}$ wiceprezydent $\mathrm{FBiH}$ oraz trzech ministrów rządu $\mathrm{BiH}^{15}$.

W dniu 28 sierpnia 2002 r. Prezydium BiH podjęło decyzję o organizacji i funkcjonowaniu instytucji obronności ${ }^{16}$. Stały Komitet Wojskowy uznano za organ polityczny i powiększono w nim sekretariat na wzór typowy dla ministerstwa. Mianowano sekretarza Komitetu i jego dwóch zastępców. Rozszerzono jego skład do siedmiu osób: trzech członów Prezydium BiH, premier BiH, minister spraw zagranicznych $\mathrm{BiH}$, prezydent/wiceprezydent RS, prezydent/wiceprezydent FBiH. Powołano komisję ds. wojskowych jako część Komitetu, która miała się zająć koordynacją aktywności sił zbrojnych w obszarze obronności, suwerenności i integralności terytorialnej $\mathrm{BiH}$.

Narzucenie reformy sektora obronności przede wszystkim stronie serbskiej ułatwiły dwie afery z przełomu 2002 i 2003 r., które skrzętnie wykorzystało OHR. W RS po tym, jak NATO niespodziewanie dokonało rewizji w przedsiębiorstwie lotniczym Orao, ustalono, że firma ta handlowała bronia z Irakiem, pomimo embarga nałożonego przez $\mathrm{ONZ}^{17}$. Serbowie wykonywali również remonty irackich samolotów MiG-21. Śledztwo wskazało także na współudział w tym procederze serbskiej firmy Jugoimport. Długo na reakcję Wysokiego Przedstawiciela nie trzeba było czekać. Pod jego naciskiem pięciu funkcjonariuszy podało się do dymisji lub zostało zdymisjonowanych. Wspólnota międzynarodowa była zaniepokojona. Szczególnie akcentowały to Stany Zjednoczone. Domagano się od rządu w Banja Luce wyjaśnień i postawienia winnych przed wymiarem sprawiedliwości.

${ }^{14}$ EUFOR: Promjena sigurnosnih aranžmana u Bosni $i$ Hercegovini, Brifing ICG ureda za Europu, Sarajevo/Brisel, 29. juni 2004, s. 1, International Crisis Group, http://www.crisisgroup.org/ /media/Files/europe/bosnia_euforia_bosn_vers.pdf (dostęp 10 II 2011).

15 H. Vetschera, dz. cyt., s. 116.

16 Zapisnik sa 148. sjednice PBiH, 26 VIII 2002, oficjalna witryna internetowa Prezydium BiH, http://www.predsjednistvobih.ba/zaklj/sjed/1/?cid=65,2,1 (dostęp 10 IX 2009).

17 В. Ковыха, Сараево: последствия „иракских дел”, „День”, 30 X 2002. 
Niedługo po tym, w dniu 7 marca 2003 r., siły SFOR dokonały rewizji w kilku bazach wojskowych bośniackich Serbów. Okazało się, że Serbowie szpiegowali nie tylko swoich obywateli oraz VFBiH, lecz również SFOR, IPTF i inne organizacje międzynarodowe ${ }^{18}$. Uznano to za poważne łamanie postanowień z Dayton. Od razu pojawiły się głosy, że bośniaccy Serbowie zapłaca wysoką cenę za afery, które w krótkim czasie wyszły na światło dzienne. W dniu 2 kwietnia 2003 r. Wysoki Przedstawiciel Paddy Ashdown wykreślił z konstytucji RS wszystkie zapisy wskazujące na państwowość tego podmiotu i zlikwidował Główną Radę Obrony ${ }^{19}$. Następnym jego krokiem było zdymisjonowanie serbskiego członka Prezydium BiH Mirko Šarovicia. Zastapił go Borislav Paravac. Ashdown wykorzystał sytuację i wprowadził zmiany. Szczególnie zależało mu na ustanowieniu struktur nadzoru nad armią na szczeblu centralnym i tak powstał projekt likwidacji Głównej Rady Obrony. Serbowie sami dali powody Wysokiemu Przedstawicielowi do takiego działania. Zlikwidowanie tego serbskiego organu do spraw obronnych było preludium do mającej nastapić reformy struktur wojskowych w Bośni.

Po aferze z serbskimi służbami wywiadowczymi w maju 2003 r., politycy z obydwóch podmiotów zgodzili się na utworzenie w połowie $2004 \mathrm{r}$. wspólnej Agencji ds. Wywiadu i Bezpieczeństwa Bośni i Hercegowiny (OSA/OBA) ${ }^{20}$. Reforma objęła odpolitycznienie tej instytucji pod nadzorem OHR. Nowa zaś kadra została przeegzaminowana pod kątem kwalifikacji i wcześniejszej służby.

Wysoki Przedstawiciel, wykorzystując atmosferę powstała po wykryciu afer, w maju 2003 r. powołał do życia specjalną Komisję ds. Reformy Obrony, która miała opracować projekt zmian w systemie obronności Bośni ${ }^{21}$. W jej skład wchodziło dwunastu członków i czterech obserwatorów: przewodniczacy Komisji, sekretarz Stałego Komitetu Wojskowego i jego dwóch zastępców, dwóch przedstawicieli podmiotów (wyznaczeni przez prezydentów podmiotów), ministrowie obrony podmiotów, zastępca Wysokiego Przedstawiciela (również jako przedstawiciel UE), przedstawiciele SFOR, NATO, OBWE oraz obserwatorzy z USA, UE, Rosji i Turcji reprezentującej Organizację Konferencji Islamskiej.

Komisja po pięciu miesiącach pracy opublikowała raport ${ }^{22}$, w którym znalazł się plan reformy obronności. Przewidywał on utworzenie Ministerstwa Obrony na szczeblu centralnym, wspólnego sztabu generalnego i dowództwa

18 T. Topić, Ešdaun u akciji, „Vreme”, 10 IV 2003.

19 Tamíe.

${ }^{20}$ OSA-OBA BiH, oficjalna witryna internetowa Agencji ds. Wywiadu i Bezpieczeństwa BiH, http://www.osa-oba.gov.ba/osaobahr.htm (dostęp 10 I 2010).

${ }^{21}$ Odluka kojom se uspostavlja Komisija za odbrambenu reformu, 9 V 2003, oficjalna witryna internetowa OHR, http://www.ohr.int/decisions/statemattersdec/default. asp?content_id=29841 (dostęp 10 V 2008).

${ }^{22}$ Put u Partnerstvo... 
operacyjnego ${ }^{23}$. Przedstawiono nową ustawę o obronności BiH oraz poprawki do konstytucji podmiotów i ustaw o obronie podmiotów. Komisja zasugerowała również przeniesienie kompetencji ze Stałego Komitetu Wojskowego na nowe centralne Ministerstwo Obrony. Projekt reformy na tym etapie nie przewidywał likwidacji armii i ministerstw obrony podmiotów. Rola tych ostatnich została ograniczona, jednak nadal miały wykonywać funkcje dotyczące przyjmowania do służby, szkoleń i wyposażenia. Armie podmiotów miały być częścią Sił Zbrojnych $\mathrm{BiH}$. Komisja zaproponowała zmniejszenie liczby profesjonalnych żołnierzy z 19 do 12 tys., a rezerwistów z 240 do 60 tys. Wskazała również na potrzebę ograniczenia przyjęć do służby zasadniczej o 50\% i skrócenia tej ostatniej z sześciu do czterech miesięcy. Podkreślono, że władze BiH muszą jak najszybciej zmniejszyć liczbę składowisk broni i amunicji oraz zniszczyć nadwyżki często starej i niestabilnej amunicji.

Najważniejsze rekomendacje Komisji zostały wykonane na przełomie 2003 i 2004 r., kiedy uchwalono pierwszą ustawę o obronie BiH i powołano centralne Ministerstwo Obrony ${ }^{24}$. Był to jednak dopiero początek zadań i wyzwań, jakie stały przed Bośnią. Opór przed połączeniem sił zbrojnych był bardzo silny. W szczególności Serbowie widzieli w swej armii gwaranta istnienia Republiki Serbskiej.

Prezydium BiH w opracowanych w marcu 2003 r. wytycznych i kierunkach polityki zagranicznej jako jeden z priorytetów wskazało integrację euroatlantycką ${ }^{25}$. Przygotowaniem do pełnego członkostwa w NATO jest program Partnerstwo dla Pokoju ${ }^{26}$. W Sarajewie liczono, że na szczycie NATO w Stambule w czerwcu 2004 r. sojusz przyjmie Bośnię do tego programu ${ }^{27}$. Bośnia rozpoczęła reformę obronności, utworzyła wspólny system dowództwa armii, co było głównym żądaniem sojuszu wobec niej. Nadal jednak niezadowalająca była współpraca BiH z ICTY. Odwiedzając Bośnię w maju 2004 r., sekretarz gene-

${ }^{23}$ J.R. Locher, M. Donley, Sprawy wojskowe: Reforma instytucji obronnych Bośni $i$ Hercegowiny, oficjalna witryna internetowa NATO, http://www.nato.int/docu/review/2004/issue4/polish/military.html (dostęp $20 \mathrm{~V}$ 2005).

${ }^{24}$ Istorija parlamentarizma u BiH, oficjalna witryna internetowa Zgromadzenia Parlamentarnego BiH, http://www.parlament.ba/istorija/default.aspx?id=28030\&langTa$\mathrm{g}=\mathrm{bs}-\mathrm{BA}$ (dostęp $10 \mathrm{~V}$ 2011).

${ }^{25}$ Opći pravci $i$ prioriteti za provođenje vanjske politike Bosne $i$ Hercegovine, 26 III 2003, oficjalna witryna internetowa Ministerstwa Spraw Zagranicznych BiH, http:// www.mfa.ba/vanjska_politika_bih/osnovni_pravci_vanjske_politike_bih/?id=2 (dostęp $10 \mathrm{~V} 2008)$.

${ }^{26}$ Więcej o Partnerstwie dla Pokoju: The Partnership for Peace programme, oficjalna witryna internetowa NATO, http://www.nato.int/cps/en/natolive/topics_50349.htm (dostęp 10 I 2010).

27 S. Numanovic, Bosna: Srbi bi mogli platiti za neuspeh, http://www.iwpr.net/sr/ report-news/bosna-srbi-bi-mogli-platiti-za-neuspeh (dostęp 10 VI 2005). 
ralny NATO Jaap de Hoop Scheffer stwierdził: „najpierw zbrodniarze wojenni, a dopiero wtedy członkostwo w programie Partnerstwo dla Pokoju i nigdy na odwrót" ${ }^{\prime 2}$. W Stambule Sojusz nie przyjął Bośni do Partnerstwa dla Pokoju. Stwierdzono, że główną przeszkodą było to, iż na wolności nadal przebywali Radovan Karadžić i Ratko Mladiće ${ }^{29}$. Wskazywano również, że proces reformy obronności nie został zakończony i że NATO nie przyjmie Bośni do Partnerstwa dla Pokoju przed utworzeniem jednolitej armii i likwidacji ministerstw obrony podmiotów, czyli de facto przejęcia całkowitej kontroli nad armią przez instytucje państwowe $\mathrm{BiH}^{30}$.

Jeszcze przed decyzja sojuszu przesłanie OHR było jasne. O ile Bośnia nie zostanie przyjęta do Partnerstwa dla Pokoju, odpowiedzialny za to będzie minister spraw wewnętrznych RS Zoran Đerić i szef tamtejszej policji Radomir Njeguš ${ }^{31}$. I rzeczywiście P. Ashdown dokonał największej czystki wśród urzędników bośniackich Serbów od powstania ich podmiotu. Zdymisjonowany został Dragan Kalinić, przewodniczacy Zgromadzenia Narodowego i lider Serbskiej Partii Demokratycznej (SDS), minister Z. Đerić oraz 59 innych funkcjonariuszy, głównie członków SDS ${ }^{32}$. Była to kara za brak współpracy z Trybunałem z Hagi. Nacisk OHR na Banja Lukę był ogromny. Wielu zadawało sobie pytanie, jak instytucje RS maja poradzić sobie ze współpraca z Haga, skoro P. Ashdown wprowadził je w ostrą fazę kryzysu politycznego.

Republika Serbska weszła w grudniu 2004 r. w następną fazę kryzysu, po tym jak NATO na szczycie w Brukseli ponownie odmówiło przyjęcia Bośni do Partnerstwa dla Pokoju ${ }^{33}$. Ashdown zareagował znowu dymisjami3 ${ }^{34}$. Zwolnił z urzędu dziewięciu wysokich funkcjonariuszy policji i władz lokalnych RS. Przy tej okazji przypomniał, że podmioty muszą przekazać kontrolę nad policją i wojskiem władzom centralnym. W tej sytuacji rząd RS Dragana Mikerevicia podał się do dymisji $^{35}$. Premier argumentował swoją decyzję tym, że nie jest w stanie przyjąc gróźb i wypełnić ultymatywnych żądań Wysokiego Przedstawiciela. Władze RS

${ }_{28}$ Tamíe.

${ }^{29}$ E. Suljagić, Kraj transatlantskog hladnog rata?!, „Dani”, 2 VII 2004.

${ }_{30}$ OSBiH: jedna vojna sila za 21. vijek. Komisija za reformu odbrane. Izvještaj 2005, s. 16, oficjalna witryna internetowa Ministerstwa Obrony BiH, http://www.mod.gov.ba/ files/file/dokumenti/Izvjestaj-2005-bs.pdf (dostęp 10 V 2009).

${ }^{31}$ S. Numanovic, $d z$. cyt.

32 G. Katana, Bosanski Srbi upozoravaju na moguce posledice Esdaunove odluke o smeni, http://www.iwpr.net/sr/report-news/bosanski-srbi-upozoravaju-na-moguce-posledice-esdaunove-odluke-o-smeni (dostęp 10 VI 2005).

${ }_{33}$ T. Markiewicz, Ewolucja systemu politycznego Bośni i Hercegowiny, [w:] Bałkany u progu zjednoczonej Europy, pod red. P. Czubika, Kraków 2008, s. 199.

${ }_{34}$ G. Katana, Nova Vlada Bosanskih Srba Ne Uliva Poverenje, http://www.iwpr.net/ sr/report-news/nova-vlada-bosanskih-srba-ne-uliva-poverenje (dostęp $10 \mathrm{~V} 2005$ ).

35 M. Milošević, Srpski demarš, „Vreme”, 23 XII 2004. 
oskarżyły OHR o łamanie postanowień układu z Dayton. Po stronie Banja Luki opowiedział się Belgrad. Wskazywano, że taka polityka wspólnoty międzynarodowej destabilizuje region i nie prowadzi do postępu w Bośni. Premier Serbii Vojislav Koštunica zwrócił szczególną uwagę na wypowiedzi P. Ashdowna o możliwości likwidacji struktur RS, które uznał za nie do przyjęcia. Przywołał porozumienie z Dayton, w którym istnienie RS jest zagwarantowane ${ }^{36}$.

Przez cały rok 2005 trwały naciski i presja OHR oraz wspólnoty międzynarodowej na bośniackich Serbów, aby wyrazili zgodę na reformę armii i policji. Ostatecznie zgodzili się oni na dokończenie reformy obronności w sierpniu 2005 r., kiedy to Zgromadzenie Narodowe RS podjęło odpowiednią uchwałę ${ }^{37}$. Dzięki tej decyzji parlament $\mathrm{BiH}$ uchwalił nową ustawę o obronie kraju ${ }^{38}$ oraz służbie w SZ $\mathrm{BiH}^{39}$. Z dniem 1 stycznia 2006 r. przestały istnieć ministerstwa obrony RS i FBiH oraz VRS i VFBiH. W myśl nowej ustawy o obronie zlikwidowano służbę zasadniczą i wprowadzono pełną profesjonalizację.

W latach 2006-2007 nowe SZ przeszły proces reorganizacji. Dokonano relokacji jednostek, zmniejszono liczbę żołnierzy do ok. 10 tys. pod koniec $2007 \mathrm{r}^{40}$ Najliczniejszą grupa etniczną w SZ są Bośniacy (45,9\%), następnie Serbowie $(33,6 \%)$, Chorwaci $(19,8 \%)$ oraz pozostali $(0,7 \%)$. Obecnie struktura SZ BiH wygląda następująco ${ }^{41}$ :

- Sztab Połązony SZ (Sarajewo);

- Dowództwo Operacyjne SZ (Sarajewo);

1) 4. Brygada Piechoty (Čapljina);

2) 5. Brygada Piechoty (Tuzla);

3) 6. Brygada Piechoty (Banja Luka);

4) bataliony artylerii (Doboj, Mostar i Žepče);

5) Brygada Sił Powietrznych i Obrony Przeciwlotniczej (Zalužani);

- Batalion Obrony Przeciwlotniczej (Sarajewo);

- Batalion Kontroli Przestrzeni Powietrznej (Zalužani);

- Batalion Wsparcia Sił Powietrznych (Sarajewo i Banja Luka);

6) Brygada Wsparcia Taktycznego (Sarajewo);

- Batalion Zmechanizowany (Tuzla);

${ }_{36}$ Tamże.

${ }^{37}$ V. Popović, Prave Bosnu po Alijinom modelu, http://www.glas-javnosti.co.yu, 2 IX 2005 (dostęp 20 IX 2005).

38 Zakon o odbrani BiH, „Službeni glasnik BiH”, br. 88/05.

39 Zakon o službi u Oružanim snagama Bosne i Hercegovine, „Službeni glasnik BiH”, br. $88 / 05$.

${ }^{40}$ Ministarstvo odbrane i Oružane snage Bosne i Hercegovine, Sarajevo 2008, s. 5.

${ }^{41}$ V. Azinović, K. Bassuener, B. Weber, Assessing the potential for renewed ethnic violence in Bosnia and Herzegovina. A security risk analysis, October 2011, s. 31-32, witryna internetowa Atlantska inicijativa, http:/www.atlantskainicijativa.org/images/stories/ ai/pdf/ai-dpc\%20bih\%20security\%20study\%20final\%2010-9-11.pdf (dostęp 10 I 2010). 
- Batalion Łączności (Pale);

- Batalion Inżynieryjny (Derventa);

- Batalion Wywiadu Wojskowego (Sarajewo);

- Batalion Saperski (Travnik);

- Batalion Żandarmerii Wojskowej (Sarajewo);

- Batalion ds. Broni Nuklearnej, Biologicznej i Chemicznej (Tuzla);

- Dowództwo Wsparcia SZ (Banja Luka);

1) Dowództwo ds. Personalnych (Banja Luka);

2) Dowództwo ds. Szkolenia i Doktryny (Travnik);

3) Dowództwo Logistyki (Doboj);

4) bataliony wsparcia logistycznego (Banja Luka, Čapljina, Tuzla, Sarajewo).

Warto zaznaczyć, że w toku tworzenia jednolitej armii Serbowie wymusili wprowadzenie tzw. systemu pułkowego. W SZ BiH istnieją trzy pułki, które kontynuują tradycję i historię armii z okresu wojny: VRS, HVO i ARBiH. Żołnierze tych pułków służą w dziewięciu monoetnicznych batalionach piechoty, które podlegaja Dowództwu Operacyjnemu SZ i rozmieszczone są w trzech multietnicznych brygadach piechoty ${ }^{42}$. Pułki nie dysponują kompetencjami operacyjnymi, lecz mają zajmować się kultywowaniem pamięci i tradycji. Wydaje się, iż taki system nie sprzyja pełnej integracji SZ BiH i może w przyszłości być zarzewiem konfliktów i sporów w SZ.

Ustawa o obronie BiH z końca 2005 r. określa, że dowodzenie i kontrolę nad SZ pełnią tylko instytucje $\mathrm{BiH}^{43}$. Na czele łańcucha dowodzenia i kontroli znajduje się Prezydium BiH, następnie minister obrony, szef Sztabu Połączonego SZ oraz dowódca Dowództwa Operacyjnego SZ. Ustawa wprowadza również kontrolę parlamentu nad SZ i innymi instytucjami działającymi w obszarze obronności ${ }^{44}$. Parlament może ogłosić stan wojenny i nadzwyczajny na wniosek Prezydium $\mathrm{BiH}$ oraz potwierdza wybór szefa Sztabu Połączonego i jego zastępców, dowódcy Dowództwa Operacyjnego i jego zastępców, dowódcy Dowództwa Wsparcia i jego zastępców oraz awans wszystkich oficerów na stopnie generalskie.

Proces ujednolicenia armii podmiotów i utworzenia SZ BiH został nagrodzony przez NATO przyjęciem Bośni do programu Partnerstwo dla Pokoju w grudniu 2006 r. ${ }^{45}$ Dzięki temu współpraca pomiędzy Bośnią i sojuszem uległa intensyfikacji. Kolejnym krokiem integracji z NATO jest Plan Działań na Rzecz Członkostwa (Membership Action Plan, MAP), który nie gwarantuje członkostwa, jednak pozwala się skupić na celach i priorytetach ustalonych w planie ${ }^{46}$.

${ }^{42}$ Tamíe, s. 33.

${ }_{43}$ Zakon o odbrani..., Član 8 (Komandovanje i kontrola).

${ }_{44}$ Tamże, Član 10 (Nadležnost Parlamentarne skupštine Bosne i Hercegovine).

${ }^{45}$ D. Wybranowski, dz. cyt., s. 229.

${ }^{46}$ Bosna i Hercegovina i NATO, Atlantska inicijativa. Udruženje za promociju euroatlantskih integracija, Sarajevo 2010, s. 14. 
Obejmują one reformy i zmiany w sektorze polityki, gospodarki, obronności oraz bezpieczeństwa i w dużej mierze pokrywaja się z wymaganiami stawianymi Bośni przez UE. Państwo biorące udział w MAP przygotowuje swój Roczny Program Narodowy (ANP) i przedstawia go sojuszowi. Następnie ministrowie spraw zagranicznych i obrony państw NATO przekazują ANP Radzie Północnoatlantyckiej, która ocenia postęp w przygotowaniach do członkostwa. Sprawozdanie o postępie w tych przygotowaniach ostatecznie muszą zaakceptować wszystkie państwa NATO.

Prezydium BiH w czerwcu 2009 r. podjęło decyzję o złożeniu wniosku o przyjęcie do MAP. W BiH liczono, że nastapi to w grudniu 2009 r. na posiedzeniu Rady Północnoatlantyckiej. Niestety brak reform, który wiązał się z pogorszeniem klimatu politycznego w Bośni, uniemożliwił przystapienie do MAP ${ }^{47}$. Szybko jednak nastapił przełom, gdyż Prezydium podjęło kilka ważnych decyzji związanych z niszczeniem nadwyżek broni, amunicji i środków wybuchowych oraz dało sygnał, że poważnie rozważa podjęcie decyzji o wysłaniu żołnierzy $\mathrm{BiH}$ do Afganistanu. Ostatecznie decyzja ta zapadła w lipcu $2010 \mathrm{r} .{ }^{48} \mathrm{Na}$ nieformalnym spotkaniu ministrów spraw zagranicznych NATO w Tallinie, w dniu 22 kwietnia 2010 r., doceniono wysiłki władz Bośni i zaproszono ten kraj do MAP $^{49}$. Zastrzeżono jednak, iż Bośnia będzie mogła korzystać z mechanizmów Planu dopiero wtedy, gdy rozwiąże kwestię majątku wojskowego. NATO domaga się, aby 69 obiektów, które Prezydium BiH uznało za perspektywiczne dla SZ, zaksięgować na Ministerstwo Obrony.

Spór o rozdysponowanie majątku wojskowego jest częścią szerszej dyskusji o podziale majątku państwowego. Ustawa o obronie $\mathrm{BiH}$ nie pozwala na obrót majątkiem wojskowym, dopóki nie zostanie wyjaśniona kwestia własności $(\text { art. } 71 \text { i } 74)^{50}$. Politycy z FBiH uważaja, że majątek wojskowy, który ma służyć SZ, powinno przejać państwo ${ }^{51}$. Natomiast RS chce zachować ów majątek w rękach podmiotów i przekazać go tylko do użytku Ministerstwu Obrony BiH. Wydaje się, że sednem sporu jest, kto będzie mógł sprzedać niepotrzebne obiekty w sytuacji, gdy zmniejszeniu ulegna potrzeby SZ - czy będzie to Ministerstwo Obrony BiH, czy też podmioty ${ }^{52}$. Szacuje się, że potrzeby SZ są znacznie mniej-

${ }^{47}$ NATO Ministers invite Montenegro to join MAP and encourage Bosnia and Herzegovina to step up reforms, 4 XII 2009, oficjalna witryna internetowa NATO, http://www. nato.int/cps/en/natolive/news_59902.htm (dostęp 10 I 2010).

48 Brošura Ministarstva obrane i Oružanih snaga BiH, travanj 2011. godine, s. 11.

${ }^{49}$ NATO Grants MAP To Bosnia, 2 V 2010, http://www.voanews.com (dostęp 10 VIII 2010).

50 Zakon o odbrani...

${ }^{51}$ D. Omeragić, Vojna imovina prekrupan zalogaj?, „Demokracija i sigurnost u jugoistočnoj Evropi” [Sarajevo] 2010, god. 1, br. 2/3, s. 62.

${ }^{52}$ Bosna i Hercegovina: Vrijeme je da Evropa djeluje, Evropski briefing $\mathrm{N}^{\circ} 59$, Sarajevo/Istanbul/Brisel, 11. januar 2011, s. 13, witryna internetowa International Crisis Gro- 
sze. Wprawdzie w dniu 9 marca 2012 r. liderzy sześciu największych partii politycznych osiagnęli porozumienie w sprawie podziału majątku wojskowego, nadal jednak brakuje odpowiedniego prawodawstwa w tym obszarze ${ }^{53}$. Strona serbska zgodziła się, aby majątek perspektywiczny został zaksięgowany na rzecz Ministerstwa Obrony BiH, a pozostały na rzecz podmiotów, kantonów i gmin. Przeprowadzeniu tego kompromisowego rozwiązania nie sprzyja jednak kampania przed wyborami lokalnymi zaplanowanymi na jesień 2012 r. Można domniemywać, że odpowiednie ustawodawstwo zostanie uchwalone na przełomie 2012 i 2013 r., co otworzy w końcu drogę do pełnego uczestnictwa w MAP.

Poważnym problemem dla SZ BiH i procesu integracji z NATO są nadwyżki broni, amunicji i środków wybuchowych, które są przechowywane w licznych obiektach w całym kraju. W ramach programu Narodów Zjednoczonych ds. Rozwoju (UNDP) obliczono, że nadwyżki wynoszą 3339 sztuk ciężkiego uzbrojenia, 65878 sztuk broni krótkiej i lekkiej oraz 22,5 tys. ton amunicji, w tym 4,5 tys. ton amunicji niestabilnej chemicznie ${ }^{54}$. Posiadanie takich nadwyżek obciąża SZ, gdyż miejsca przetrzymywania broni i amunicji muszą być strzeżone przez żołnierzy, aby nie dochodziło do kradzieży. Po drugie, amunicja niestabilna chemicznie może w każdym momencie wybuchnąc i wyrządzić olbrzymie szkody. Prezydium BiH określiło trzy metody likwidacji nadwyżek: niszczenie, przekazanie i sprzedaż, przy czym wspólnota międzynarodowa preferuje raczej tę pierwszą metodę ${ }^{55}$. Spory polityczne uniemożliwiaja jednak szybkie pozbycie się nadwyżek przede wszystkim amunicji. Mniej niebezpieczna jest bron krótka i lekka, którą łatwiej sprzedać bądź podarować, jak to stało się z 6 tys. AK-47s podarowanymi afgańskiej armii w 2011 r. ${ }^{56}$

Następną przeszkodą w procesie integracji BiH z NATO może stać się zmiana polityki w tej mierze największej partii serbskiej w tym kraju - Związku Niezależnych Socjaldemokratów (SNSD). Do 2010 r. partia ta nie sprzeciwiała się pełnemu członkostwu Bośni w Pakcie. Od momentu nawiązania sojuszu na szczeblu centralnym z SDS po wyborach w 2010 r. SNSD coraz częściej i głośniej mówi o potrzebie przeprowadzenia referendum $\mathrm{w} \mathrm{RS} \mathrm{w}$ sprawie przystapienia $\mathrm{BiH}$ do NATO oraz krytykuje i uwypukla wszystkie nieprawidłowości w SZ ${ }^{57}$. Politycy

up, http://www.crisisgroup.org/ /media/Files/europe/balkans/bosnia-herzegovina/B59\%20 Bosnia\%20-\%20Europes\%20Time\%20to\%20 Act\%20BOSNIAN.pdf (dostęp 10 VII 2011).

${ }^{53}$ M. Bjelajac, Šestorka postigla dogovor o vojnoj $i$ državnoj imovini, http://www. slobodnaevropa.org/content/sestorka_postigla_dogovor_o_vojnoj_i_drzavnoj_imovini/24510798.html (dostęp 10 IV 2012).

${ }^{54}$ Disposal of Surplus of Weapons and Ammunition in AF BiH. Management of Storage Sites, Expert Working Group, http://www.rasrinitiative.org/pdfs/workshop-3/RASRworkshop-EWG-Surplus-in-AF-BiH-3Nov10.pdf (dostęp 10 XI 2011).

${ }^{55}$ V. Azinović, K. Bassuener, B. Weber, dz. cyt., s. 36.

56 Tamíe.

${ }^{57}$ I. Beridan, Sigurnosne integracije i Bosna i Hercegovina, [w:] Međunarodni simpozij. Bosna i Hercegovina - 15 godina Dejtonskog mirovnog sporazuma. Zbornik radova, 
tego ugrupowania argumentuja, że Bośni w obliczu katastrofalnej sytuacji gospodarczej nie stać na SZ i proponują pełną demilitaryzacje ${ }^{58}$. Odmienne stanowisko reprezentuja główne partie bośniackie i chorwackie. Brak konsensusu w tej sprawie może spowolnić bądź całkowicie wyhamować proces integracji z NATO.

Warto zauważyć, że argumenty o kosztach reformy armii i samego procesu integracji z Sojuszem są częściowo uzasadnione. W zamian jednak nastapiła racjonalizacja wydatków na SZ, powstały profesjonalne, dobrze wyszkolone i uzbrojone SZ. Nie można zapominać również o tym, iż członkostwo w Sojuszu Północnoatlantyckim może przyciagnąć kapitał zagraniczny. Pamiętać należy zarazem, że Sojusz może bronić BiH przed agresją z zewnątrz, która jest raczej mało realna, jednak nie zagwarantuje, że nie dojdzie do konfliktu wewnętrznego ${ }^{59}$. Widmo tego ostatniego niestety nadal występuje przy braku konsensusu wśród polityków w podstawowych sprawach dotyczących tego kraju. Wskazuje się, iż ta groźba w warunkach malejącego zaangażowania wspólnoty międzynarodowej w Bośni nie została usunięta, lecz tylko odłożona w czasie ${ }^{60}$. Bez zmian w systemie politycznym BiH, które usprawnią instytucje państwowe i uniemożliwią blokadę systemu, członkostwo w NATO nie będzie w stanie przynieść pożądanych efektów.

Zaznaczyć należy także, że nadzieje, iż członkostwo Bośni w NATO i UE rozwiąże jej wszystkie problemy instytucjonalne, gospodarcze, socjalne i inne, sa błędne. Proces integracji z tymi organizacjami może Bośni pomóc, jednak nie może być on celem samym w sobie. Dodatkowo dyskursowi temu towarzyszą postulaty przyspieszenia procesu integracji euroatlantyckiej przy obniżaniu wymagań, co może przynieść efekt przeciwny od oczekiwanego $0^{61}$. Politycy musza znać jasne i twarde warunki, po spełnieniu których Bośnia może liczyć na członkostwo. Obniżanie standardów i wymogów będzie rozwijać demotywację i pasywność bośniackich polityków.

Na zakończenie warto wspomnieć o misjach pokojowych, w których żołnierze z Bośni brali dotychczas bądź nadal biorą udział. W lutym 2005 r. Sarajewo wysłało do Iraku 36-osobowy pluton ${ }^{62}$. Jednostka ta od grudnia 2006 r. znalazła

ur. H. Bašić, F. Muslić, Sarajevo 2011, s. 114; Referendum o NATO!, 3 XI 2010, http://www. vesti.rs (dostęp 10 I 2012); Džombić: RS za referendum o ulasku u NATO, 26 X 2011, http:// www.nezavisne.com (dostęp 10 I 2012).

${ }^{58} \mathrm{Da}$ li demilitarizacija BiH bilo dobro rješenje?, 27 I 2009, http://www.voanews. com (dostęp 10 V 2010); D. Momić, Oružane snage BiH su svetsko čudo. Na 3.700 vojnika 5.100 starešina?!, 8 XI 2011, http://www.pressrs.ba (dostęp 10 I 2010).

${ }^{59}$ K. Bassuener, Samo američki angažman može izvući Bosnu, „Demokracija i sigurnost u jugoistočnoj Evropi” 2011, god. 2, br. 6/7, s. 11.

${ }^{60}$ M. Pejanović, Politički razvitak Bosne i Hercegovine u postdejtonskom periodu, Sarajevo 2005, s. 141.

${ }^{61} \mathrm{~K}$. Bassuener, dz. cyt.

${ }^{62}$ D. Wybranowski, dz. cyt., s. 228. 
się w składzie Wielonarodowej Dywizji Centrum Południe na terenie polskiej strefy. Bośniaccy żołnierze (w sumie 288) brali udział w operacji „Iracka Wolność" przez 3,5 roku ${ }^{63}$. Saperzy zniszczyli około 350 tys. min i innych środków wybuchowych. BiH w znacznie skromniejszym wymiarze zaznaczyła swoja obecność w misji pokojowej w Kongu (MONUC, wcześniej MONUSCO), w której uczestniczy od 2002 r. Obecnie przebywa tam pięciu bośniackich obserwatorów wojskowych $^{64}$. Podobny charakter miał udział w misji pokojowej w Erytrei i Etiopii, która trwała od 2001 do 2008 r. i w której uczestniczyło w sumie 59 obserwatorów wojskowych. W marcu 2009 r. minister obrony BiH Selmo Cikotić podpisał umowę o udziale SZ BiH w misji ISAF (International Security Assistance Force). $\mathrm{BiH}$ została 42. członkiem ISAF ze statusem non-NATO Contributing Nation (NNCN). Poczatkowo Bośnia wysłała do Afganistanu 10 oficerów do prac sztabowych $^{65}$. Pierwszy pełen kontyngent (45 żołnierzy) przybył do prowincji Helmand w dniu 21 października 2010 r. ${ }^{66}$ Żołnierze bośniaccy służący w Afganistanie nie biora udziału w bezpośrednich działaniach bojowych i pełnią tylko funkcje ochrony duńskiej bazy w prowincji Helmand ${ }^{67}$. Na początku 2012 r. BiH wysłała do Afganistanu pierwszą grupę instruktorów żandarmerii wojskowej (sześciu oficerów), którzy w akademii żandarmerii wojskowej w Kabulu szkolą i trenuja swoich afgańskich odpowiedników ${ }^{68}$.

${ }^{63}$ Bosna i Hercegovina i NATO..., s. 22.

${ }^{64}$ Učešce pripadnika OS BiH u UN misjiama, „Bilten Ministarstva obrane-odbrane i Oružanih snaga Bosne i Hercegovina”, novembar/studeni 2010, br. 5, s. 10-11.

65 Učešce pripadnika OS BiH u misiji ISAF (snage međunarodne sigurnosne pomoći) u Afganistanu, ,Bilten Ministarstva obrane-odbrane i Oružanih snaga Bosne i Hercegovina”, maj/svibanj 2010, br. 4, s. 7 .

${ }^{66}$ Jedinica Oružanih snaga BiH u misiji u Afganistanu, „Bilten Ministarstva obrane-odbrane i Oružanih snaga Bosne i Hercegovina”, novembar/studeni 2010, br. 5, s. 4.

${ }^{67}$ M. Jusić, Helmand, geografija nesigurnosti, „Demokracija i sigurnost u jugoistočnoj Evropi” 2010, god. 1, br. 4/5, s. 51.

${ }_{68}$ Војно-полицијска школа у мисији ИСАФ, „Bilten Ministarstva obrane-odbrane i Oružanih snaga Bosne i Hercegovina", april/travanj 2012, br. 7, s. 17. 